This work was supported by the Commission for Medical Research Belgrade.

Institute for Medical Research,

Academy of Sciences and Arts, Zagreb,

Yugoslavia.

${ }^{1}$ Csapo, A., and Wilkie, D. R., J. Physiol., 134, 497 (1956).

${ }^{2}$ Grieve, D. W., J. Physiol., 152, 25, P (1960).

${ }^{3}$ Lorkovic, H., Amer. J. Physiol., 196, 666 (1959).

'Lorkovic, H., Pfingers Arch., 272, 45 (1960).

\section{Fatigue in a Fluid-filled Pulsating Elastic Tube}

EXPERIMENTs with the 'oscillator' described by $m^{1}$ have shown that fatizue affects the elastic tube, after it has been pulsating for several hours.

Aneurysmal-like bulges may occur. Alternatively, a small hole forms at the end close to the rigid outlet tube, presumabiy due to cavitation occurring in contact with the wall. Fluid may escape from this hole, or air be sucked in, at each pulse.

A remarkable effect is obtained by the application of cedar wood oil. Within a few minutes, the distal segment of the elastic tube, when so treated, becomes permanently stretched into a sigmoid shape and develops periodic constrictions and dilatations, affecting the system of short wave-length, that is in the range $1-2 \mathrm{~cm}$.

These figures resemble the shapes of arteries in atherosclerosis.

\section{John Erskine Malcolm}

Postgraduate Medical School of London, Ducane Road, London, W.12.

${ }^{1}$ Nature, 190, 88 (1961).

\section{PHARMACOLOGY}

\section{Alleged Anticomplementary Effect of Aspirin}

VAN Oss et al. ${ }^{1}$ recently reported that aspirin at concentrations of $2.2 \times 10^{-3} M(40 \mathrm{mgm} . / 100 \mathrm{ml}$.) inhibited the lysis of red cells in a simple complementhæmolysis reaction, but that sodium salicylate was inactive. This was interesting in view of the therapeutic action of aspirin against diseases such as the rheumatic disorders which are thought to involve immunological phenomena ${ }^{2}$. Two other related compounds, salicylaldoxime and salicylaldehyde, were earlier reported ${ }^{3}$ to inhibit red cell lysis in a similar reaction. I therefore investigated the complement-hæmolysis technique since it might usefully predict anti-rheumatic activity in other salicylate derivatives.

Sheep erythrocytes $(E)$, anti-sheep erythrocyte serum prepared in the rabbit $(A)$ and complement $\left(C^{\prime}\right)$ were standard serological reagents obtained from the Commonwealth Serum Laboratories, Melbourne. Complement was received as ampoules of freeze-dried guinea pig serum which was reconstituted with distilled water and stored at $4^{\circ} \mathrm{C}$. It gave results identical with fresh guinea pig serum prepared in these laboratories. Barbital buffer, $p$ H $7 \cdot 4$ and containing added $\mathrm{Mg}^{++}$and $\mathrm{Ca}^{++}$, was prepared according to Mayer et al. ${ }^{4}$ and diluted 1 in 5 with distilled water on the day of use. All reagents were diluted in barbital buffer. When $0.1 \mathrm{ml}$. of a 2 per cent suspension of washed erythrocytes was sensitized with $0.1 \mathrm{ml}$, of antiserum $1 / 1,000$, the addition of $0.5 \mathrm{ml}$. of guinea pig serum 1/200 caused complete hæmolysis of the erythrocytes within $30 \mathrm{~min}$. at $37^{\circ} \mathrm{C}$. The effect of added substances on the progress of the $C^{\prime}$ hæmolysis was determined by placing $0 \cdot 25$ ml. of guinea pig serum 1/100 into hæmolysis tubes and adding $0.25 \mathrm{ml}$. of a solution of the compound in barbital buffer. The latter solution was replaced by buffer alone in control tubes. The diluted antiserum and red blood cells were then added and the tubes incubated at $37^{\circ} \mathrm{C}$. for $30 \mathrm{~min}$. The $p \mathrm{H}$ of the solutions prior to incubation was determined with a glass electrode in duplicate tubes, which were prepared for each concentration of the compound under test.

The substances I have investigated and the concentrations that caused an approximate 50 per cent inhibition of hæmolysis in our procedure are shown in Table 1. All the acids decreased the $p H$ of the final mixture proportional to their concentration, and the $p \mathrm{H}$ range at the concentrations where hæmolysis was inhibited are shown in column 2. Where applicable I have included the inhibitory concentrations reported by other workers for comparison.

Table 1. SUBSTANCES WHICH INHIBITED COMPLEMENT-HARMOLYSIS AND THEIR EFFECT ON THE $p$ H OF THE REACTION MIXTURE

\begin{tabular}{|c|c|c|c|c|}
\hline Compound & $\begin{array}{l}\text { Concentrations } \\
\text { (molar) giving } \\
50 \text { per cent } \\
\text { inhibition of } \\
\text { hæmolysis in } \\
30 \text { min. }\end{array}$ & $\begin{array}{l}p \text { H ranges of } \\
\text { the reaction } \\
\text { mixtures at } \\
\text { the inhib- } \\
\text { itory con- } \\
\text { centrations }\end{array}$ & $\begin{array}{l}\text { Concentra- } \\
\text { tions (molar) } \\
\text { elsewhere } \\
\text { reported to } \\
\text { inhibit com- } \\
\text { plement- } \\
\text { hæmolysis }\end{array}$ & $\begin{array}{l}\text { Ref. } \\
\text { No. }\end{array}$ \\
\hline $\begin{array}{l}\text { Aspirin } \\
\text { Salicylic acid }\end{array}$ & $\begin{array}{l}2-3 \times 10^{-3} \\
2-3 \times 10^{-3}\end{array}$ & $\begin{array}{l}5 \cdot 8-6 \cdot 4 \\
5 \cdot 8-6 \cdot 4\end{array}$ & $\begin{array}{c}2 \cdot 2 \times 10^{-3} \\
10 \text { per cent } \\
\text { inhibition } \\
3 \cdot 3 \times 10^{-3}\end{array}$ & 1 \\
\hline $\begin{array}{l}\text { Sodium } \\
\text { salicylate }\end{array}$ & No inhibition & $7 \cdot 4$ & No inhibi- & 1 \\
\hline Fumaric acid & $2-3 \times 10^{-2}$ & $5 \cdot 8-6 \cdot 2$ & - & 1 \\
\hline $\begin{array}{l}\text { acid } \\
\text { Salicylaldoxime } \\
\text { Salicylaldehyde }\end{array}$ & $\begin{array}{c}2-3 \times 10^{-8} \\
8 \times 10^{-4} \\
8 \times 10^{-4}-10^{-8}\end{array}$ & $\begin{array}{c}5 \cdot 8-6 \cdot 4 \\
7 \cdot 5 \\
7 \cdot 3\end{array}$ & $\begin{array}{c}5 \times 10^{-4} \\
2 \cdot 5 \times 10^{-4}\end{array}$ & $\begin{array}{l}-\overline{3} \\
3\end{array}$ \\
\hline
\end{tabular}

Several important points emerge from Table 1. The capacity of the diluted Mayer solution was clearly inadequate to buffer the effects of the acidic compounds on the $p H$ of the hrmolytic reaction. Furthermore, it seemed strange that while salicylic acid inhibited hæmolysis, sodium salicylate at similar concentration was inactive-yet at $p \mathrm{H}$ values above 5 , both compounds would be in solution in identical form as salicylate ions. Finally all the acids tested inhibited my hæmolytic reaction at approximately the same molar concentration $(2-3 \times$ $\left.10^{-3}\right)$, hydrochloric acid being just as effective as the organic acids. At this concentration they reduced the $p \mathrm{H}$ of the reaction from $7 \cdot 4$ to about 6 . It appeared likely therefore that inhibition of hæmolysis was due in some manner to the $p \mathrm{H}$ shift rather than a specific anticomplementary action. This explanation was further justified when the above experiments were repeated using undiluted Mayer buffer, the tonicity of which was adjusted by omitting some of the sodium chloride. Under these conditions hæmolysis was complete within $30 \mathrm{~min}$. in the absence of a test compound and was inhibited by salicylaldehyde and salicylaldoxime at the same concentrations as in the dilute buffer. However, none of the other substances in Table 1 lowered the $p H$ of the final mixture below 7.0 or caused any inhibition of complement-induced 